\title{
Bone disease after jejuno-ileal bypass for morbid obesity
}

\author{
I. T. GILMORE* \\ M.D., M.R.C.P. \\ W. R. ELLIS \\ M.B., M.R.C.P. \\ S. FENTON \\ B.Sc. \\ E. HARRIS \\ Med. Anal (Ned)
}

J. B. EASTWOOD

M.D., F.R.C.P.

V. A. LUCK

B.Sc.

A. J. O'GRADY

B.Sc.

I. M. MURRAY-LYON

M.D., F.R.C.P.

Departments of Medicine and Chemical Pathology, Charing Cross Hospital, London W6 8RF

\section{Summary}

Fifteen patients who had undergone a 14 inches $\times 4$ inches jejuno-ileal bypass operation for obesity, 3 to 4 years earlier, were investigated by iliac bone biopsy, radiology and routine biochemistry, including 25hydroxy-vitamin $\mathbf{D}$ and parathyroid hormone estimations. Two patients had histological osteomalacia which was mild in one. A further 9 patients had abnormal bone biopsies, there being an excess of trabecular bone surface covered by osteoid with a normal or reduced amount of calcification front. Six of these 9 showed an increase in trabecular resorption, although in none were there excessive numbers of osteoclasts. The likely explanation for these findings is that these 9 patients had early osteomalacia with mild hyperparathyroidism, making a total of 11 patients out of 15 with osteomalacia. Radiology and blood chemistry were poor predictors of histological bone disease.

KEY WORDS: obesity, jejuno-ileal bypass, osteomalacia, hyperparathyroidism.

\section{Introduction}

Bypass of the small intestine is an established treatment for morbid obesity, more than 6000 operations having been reported by 1976 (Phillips, 1978). Although osteomalacia is a possible complication of this procedure, it was not systematically studied until 1978 when Compston et al. (1978) reported histological osteomalacia in 10 of 21 unselected patients who had undergone surgery at least 3 years earlier. This

Present address: Gastroenterology Unit, Royal Liverpool Hospital, Prescot Street, Liverpool L7 8XP. unexpectedly high prevalence requires confirmation, for it implies that thousands of patients are at risk from metabolic bone disease.

Patients and methods

\section{Patients}

A standard end-to-side jejunal bypass operation, leaving 14 inches of jejunum and 4 inches of ileum in continuity (Payne and DeWind, 1969), had been performed on 20 patients between April 1974 and September 1975 (Mr B.P. Bliss) (Table 1). Fifteen agreed to be investigated. There were 11 women and 4 men, aged 31 to 64 years (mean 48 years). Preoperative body weights ranged from $105 \mathrm{~kg}$ to $153 \mathrm{~kg}$ (mean $133 \mathrm{~kg}$ ). Weight loss following the operation was 18 to $71 \mathrm{~kg}$ (mean $47 \mathrm{~kg}$ ), and none had significant symptoms of bone pain or tenderness. Although all but one had diarrhoea, with a daily stool frequency of 3 to 20,14 were delighted with the results of the operation. One patient (patient 11) was receiving oral treatment with $62 \mu \mathrm{g}$ of cholecalciferol and $64 \mathrm{mg}$ of calcium daily; the remaining patients were on no therapy apart from anti-diarrhoeal agents.

\section{Methods}

Blood samples were taken for serum calcium, phosphorus and alkaline phosphatase. Plasma 25OH-vitamin D was measured by a competitive protein-binding assay (Haddad and Chyu, 1971) and plasma parathyroid hormone by two methods, a sensitive bioassay (Chambers et al., 1978; Fenton, 
Somers and Heath, 1978) and a double antibody technique (Conaway and Anast, 1974) using a Cterminal-specific antibody (E. Slatopolsky, Washington University School of Medicine, St. Louis, Missouri). All patients were submitted to a radiographic survey of the skeleton including films of hands, feet, pelvis and thoraco-lumbar spine.

The iliac bone biopsies were taken between April and September, 1978. The procedure (Bordier et al., 1964) was done under local anaesthetic, the patient having received $1800 \mathrm{mg}$ oral dimethylchlortetracycline over 2 days, 1 week earlier. The biopsy was of the through-and-through type and was taken from an area about $5 \mathrm{~cm}$ below the right iliac crest, a cylinder of bone $5 \mathrm{~mm}$ in diameter and consisting of the 2 cortices with intervening cancellous bone being obtained. Undecalcified sections, $6 \mu \mathrm{m}$ thick, were prepared and stained with toluidine blue (Eastwood et al., 1974), and measurements made in the area between the cortices, i.e. in the cancellous region (Bordier and Tun Chot, 1972; Bordier et al., 1973; Merz and Schenk, 1970). Using a point sampling graticule (Zeiss I), values were obtained for total bone tissue as a percentage of total cancellous volume and for the area occupied by osteoid as a proportion of total bone tissue. Using a graticule consisting of parallel lines (Zeiss II), the proportion of trabecular surface covered by osteoid and that showing resorption were measured. When graticule lines intersected osteoid, it was further noted whether there was evidence of calcification front, expressed as a percentage of osteoid surface. The numbers of osteoclasts were counted and expressed per unit area of section. Unstained sections were examined under ultraviolet light for tetracycline fluorescence.

\section{Results}

\section{Histology}

Bone histology was abnormal in 11 of the 15 patients (Table 2). In 2 patients (patients 1 and 2), there was an increase in volume of osteoid together with a diminution in calcification front, i.e. classical osteomalacia, mild in one. In the remaining 9 patients (patients 3-11) with abnormal histology, there was an increase in trabecular surface covered by osteoid, but a normal volume of osteoid. The extent of calcification front quantitated on toluidine blue stained slides was normal or reduced, an observation that was confirmed on tetracycline fluorescence. One of these 9 patients was exceptional in that he had an increase in volume of osteoid, but because there was a normal amount of calcification front he has not been considered as having osteomalacia. In 6 of the 9 patients, there was an increase in trabecular resorption (expressed as percentage of 'available' surface), but the number of osteoclasts was normal. In the remaining 4 patients (patients 12-15), there was no histological abnormality apart from osteopenia in two.

\section{Plasma biochemical values and X-rays}

Plasma values were largely unhelpful in detecting histological bone disease. Nevertheless, one of the 2 patients with a particularly low plasma calcium had histological osteomalacia. Plasma ionised calcium (range 1.09-1.21 mmol/litre, 4.36-4.84 mg/100 ml) was normal in all 11 patients in whom it was measured (patients 3, 4, 7-15). Three patients had a raised serum concentration of alkaline phosphatase; two (patients 1 and 14) of these had cirrhosis of the liver with raised plasma $\gamma$-glutamyl-transpeptidase concentrations. Plasma 25-OH-vitamin D was low in 6 of the 15 patients, but no lower in those with bone disease than in those without; nevertheless the two with osteomalacia were among the 6 low values. Plasma levels of parathyroid hormone were raised in 3 patients by cytochemical assay and in 7 patients by C-terminal assay. The blood urea (range 2.0-5.3 mmol/litre, $12.0-31.8 \mathrm{mg} / 100 \mathrm{ml}$ ) and plasma creatinine (range 44-105 $\mu \mathrm{mol} / \mathrm{litre}, 0.5-1.2 \mathrm{mg} / 100 \mathrm{ml}$ ) were normal in all 15 patients.

Skeletal radiographs revealed no evidence of metabolic bone disease in any patient.

\section{Clinical features}

Stool frequency was unrelated to histological bone disease, but the 2 patients with osteomalacia were among 5 who had lost more than $55 \mathrm{~kg}$ since the operation.

\section{Discussion}

This study of 15 patients 3 to 4 years after jejunoileal bypass, shows that the majority (11 patients) had histological abnormalities in the bone. In 2 patients, there was clear evidence of osteomalacia, in that there was an excessive volume of osteoid tissue as well as a diminution in calcification front. In a further 9 patients, although the volume of osteoid was normal, there was an increase in trabecular surface covered by osteoid and the amount of calcification front was normal or reduced. Six of these 9 patients showed an increase in the amount of trabecular surface showing resorption. These findings are similar to those reported by Parfitt et al. (1978) who performed bone biopsies in 10 patients who had been selected because of suspicion of metabolic bone disease from a group of 52 patients with a jejuno-ileal bypass. They found an increase in the amount of trabecular surface showing resorption in 5 patients, and their measurements of osteoid showed that the rate of osteoid formation and mineralisation was reduced in all 10 patients. In other words, the 
TABLE 2. Quantitative bone histology data in the 15 patients. (In patients 4 and 9 , the very high value for total bone tissue is accounted for by biopsy being mainly of iliac crest).

\begin{tabular}{|c|c|c|c|c|c|c|}
\hline \multirow[b]{2}{*}{ Patient } & \multicolumn{2}{|c|}{ Volumes } & \multicolumn{3}{|c|}{ Surfaces } & \multirow[b]{2}{*}{$\begin{array}{l}\text { Osteoclasts } \\
\text { (number per sq. mm } \\
\text { of bone section) }\end{array}$} \\
\hline & $\begin{array}{c}\text { Total bone } \\
\text { tissue } \\
\text { (\% of total } \\
\text { cancellous } \\
\text { volume) }\end{array}$ & $\begin{array}{c}\text { Osteoid } \\
\text { (\% of total } \\
\text { bone tissue) }\end{array}$ & $\begin{array}{l}\text { Trabecular } \\
\text { surface } \\
\text { covered by } \\
\text { osteoid } \\
(\%)\end{array}$ & $\begin{array}{l}\text { Calcification } \\
\text { front }^{*} \\
(\%)\end{array}$ & $\begin{array}{c}\text { Resorption } \\
\text { (\% of available } \\
\text { surface) } \dagger\end{array}$ & \\
\hline 1 & $12 \cdot 6$ & $17 \cdot 3$ & 68.9 & $31 \cdot 1$ & $73 \cdot 3$ & $0 \cdot 19$ \\
\hline 2 & 15.0 & $9 \cdot 8$ & $75 \cdot 4$ & $37 \cdot 8$ & $76 \cdot 7$ & 0.13 \\
\hline 3 & $21 \cdot 5$ & $7 \cdot 1$ & $62 \cdot 1$ & 43.9 & $59 \cdot 7$ & 0.14 \\
\hline 4 & $52 \cdot 1$ & $2 \cdot 5$ & 56.9 & $43 \cdot 1$ & $39 \cdot 5$ & 0.05 \\
\hline 5 & 12.0 & 7.0 & $64 \cdot 5$ & $63 \cdot 1$ & 33.9 & 0.12 \\
\hline 6 & $12 \cdot 9$ & $10 \cdot 6$ & $70 \cdot 6$ & $73 \cdot 2$ & $62 \cdot 9$ & 0.09 \\
\hline 7 & 16.4 & 1.9 & $31 \cdot 3$ & $56 \cdot 7$ & $41 \cdot 3$ & 0.27 \\
\hline 8 & $11 \cdot 5$ & $7 \cdot 1$ & $47 \cdot 2$ & $72 \cdot 9$ & $26 \cdot 3$ & 0 \\
\hline 9 & 51.9 & $4 \cdot 0$ & $54 \cdot 5$ & $51 \cdot 2$ & $29 \cdot 2$ & $0 \cdot 10$ \\
\hline 10 & $20 \cdot 4$ & 3.0 & $34 \cdot 5$ & $48 \cdot 7$ & $10 \cdot 6$ & $0 \cdot 11$ \\
\hline 11 & $14 \cdot 5$ & $4 \cdot 6$ & $48 \cdot 5$ & $48 \cdot 0$ & $17 \cdot 4$ & 0.01 \\
\hline 12 & $7 \cdot 7$ & $1 \cdot 2$ & $23 \cdot 5$ & $58 \cdot 0$ & $11 \cdot 0$ & 0 \\
\hline 13 & $19 \cdot 1$ & $1 \cdot 2$ & 21.9 & 53.4 & $23 \cdot 2$ & 0 \\
\hline 14 & $8 \cdot 6$ & $1 \cdot 8$ & $16 \cdot 5$ & $53 \cdot 3$ & $22 \cdot 1$ & 0 \\
\hline 15 & 16.0 & 1.5 & $9 \cdot 4$ & 65.9 & $9 \cdot 3$ & 0 \\
\hline $\begin{array}{c}\text { Normal } \\
\text { subjects } \\
\pm \text { s.d. } \neq\end{array}$ & $\S$ & $5 \cdot 7 \pm 2 \cdot 0$ & $14 \cdot 6 \pm 6 \cdot 0$ & $78 \cdot 0 \pm 7 \cdot 0$ & $17 \cdot 8 \pm 4 \cdot 4$ & $<0.30$ \\
\hline
\end{tabular}

* Extent of osteoid showing calcification front expressed as \% of total extent of osteoid.

†'available' surface is trabecular surface not covered by osteoid i.e. available for resorption.

$\ddagger$ Bordier and Tun Chot (1972); Bordier et al. (1973).

§Age 30-39, $21.1 \pm 4 \cdot 05 ; 40-49,21 \cdot 0 \pm 4 \cdot 01 ; 50-59,19.6 \pm 4 \cdot 15 ; 60-69,19 \cdot 1 \pm 4 \cdot 90$ (Merz and Schenk, 1970).

increase in trabecular resorption was probably due not only to increased resorption, but also to diminished repair. It is quite probable, therefore, that our 9 patients and those of Parfitt et al. (1978) were manifesting early osteomalacia; indeed Parfitt et al. (1978) considered 3 of their patients to have unequivocal osteomalacia. Mosekilde et al. (1980) have reached similar conclusions.

Definite histological evidence of hyperparathyroidism in our patients was lacking. Nevertheless, as mentioned above, 6 of the 9 patients showed an increase in trabecular surface showing resorption, although the number of osteoclasts was normal. Circulating levels of parathyroid hormone were raised in 6 out of 7 patients using the C-terminal immunoassay, but in only 3 of these 6 patients by cytochemical assay. A possible explanation for this discrepancy is that the C-terminal assay is known to recognise at least one fragment as well as whole hormone (Arnaud et al., 1974), whereas the cytochemical assay, which measures biological activity, recognises whole hormone but not C-terminal frag- N ments. Our findings are similar to those of Parfitt et al. (1978) who, in addition to finding increased resorption in 5 patients, found raised levels of parathyroid hormone by C-terminal assay in 3 out of 10 patients. As in our patients, osteoclast numbers were normal. It $\varrho$ is probable that in both series, the patients had mild hyperparathyroidism, as has been suggested by others? (Compston et al., 1978; Thode, Madsen and Hey, T 1978), in addition to the defect in osteoid formation and mineralisation mentioned earlier. 
In other words, our 15 patients show a spectrum of histological appearances from normality to classical osteomalacia. In this study and the study from Mosekilde et al. (1980), there is no evidence to support the suggestion of a bone disease characterised by bone loss and possibly due to absorption from the bowel of 'resorptive factors' such as endotoxin (Simmonds et al., 1975; Fumarola, 1978). The incidence of osteomalacia varies in different reports. Compston et al. (1978) found histological evidence of osteomalacia in 10 out of 21 patients studied up to 7 years after bypass. It is possible that the higher incidence in their series as compared with those of Parfitt et al. (1978), Baddeley (1979) and ourselves is related to the type of operation performed. In the series of Compston et al. (1978), the majority of patients had had almost complete bypass of the jejunum, only 4 inches remaining compared with 14 inches in the present series, so it is possible that there was greater interference with vitamin D absorption in the jejunum in their patients than in ours. Another factor to be considered is the interval between operation and the assessment of bone histology.

To our knowledge there are no quantitative histological studies of bone in untreated grossly obese patients. Therefore, before concluding that the abnormalities seen in the bone biopsies in the present and other studies are related to the bypass procedure, it is important to know that the bones are normal at the time of operation. Until detailed studies of bone histology are carried out, both before and at intervals after the operation, with particular attention being paid to the type of operation performed, the relationship between obesity, bypass procedures and bone disease will remain uncertain. Nevertheless, doctors involved in the care of these patients should be aware of the high risk of bone disease which may not be detected by conventional radiology and biochemistry.

\section{Acknowledgments}

The bone histology was performed with the aid of a grant from the National Kidney Research Fund (J.B.E. and E.H.). We thank Janice Cam for measuring plasma ionised calcium. We are grateful to Professor H. E. de Wardener for helpful discussions during the preparation of this manuscript, and to Mrs V. Brooke for secretarial help. The PTH measurements were made under a grant from the Medical Research Council.

\section{References}

Arnaud, C.D., Goldsmith, R.S., Bordier, P.J. \& Sizemore, G.W. (1974) Influence of immunoheterogeneity of circulating parathyroid hormone on results of radioimmunoassays of serum in man. American Journal of Medicine, 56, 785.

BADDELEY, R.M. (1979) The management of gross refractory obesity by jejuno-ileal bypass. British Journal of Surgery, 66, 525 .

Bordier, P.J., Matrajt, H., Miravet, L. \& Hioco, D. (1964) Mésure histologique de la masse et de la résorption des travées osseuses. Pathologie et Biologie, 12, 1238.

BORDIER, P.J. \& TUN CHOT, S. (1972) Quantitative histology of metabolic bone disease. Clinics in Endocrinology and Metabolism, $1,197$.

Bordier, P.J., TUN ChOt, S. EASTWOOd, J.B., FouRnier, A.E. \& DE WARDENER, H.E. (1973) Lack of histological evidence of vitamin D abnormality in the bones of anephric patients. Clinical Science, 44, 33.

Chambers, D.J., Dunham, J., Zanelli, J.M., Parsons, J.A., BitenSKY, L. \& CHAYEN, J. (1978) A sensitive bioassay of parathyroid hormone in plasma. Clinical Endocrinology, 9, 375.

COMPSTON, J.E., HORTON, L.W.L., LAKER, M.F., WOOdHEAD, J.S., Gazet, J.C., AYers, A.B., Bull, H.J. \& Pilkington, T.R.E. (1978) Bone disease after jejuno-ileal bypass for obesity. Lancet, ii, 1.

CONAWAY, H.H. \& ANAST, C.S. (1974) Double antibody radioimmunoassay for parathyroid hormone. Journal of Laboratory and Clinical Medicine, 83, 129.

Eastwood, J.B., Bordier, P.J., Clarkson, E.M., Tun Chot, S. \& DE WARDENER, H.E. (1974) The contrasting effects on bone histology of vitamin D and of calcium carbonate in the osteomalacia of chronic renal failure. Clinical Science and Molecular Medicine, 47, 23.

Fenton, S., Somers, S. \& Heath, D.A. (1978) Preliminary studies with the sensitive cytochemical assay for parathyroid hormone. Clinical Endocrinology, 9, 381.

FUMAROLA, D. (1978) Bone disease after jejuno-ilial bypass. Lancet, ii, 678.

HADDAD, J.G. \& CHYU, K.J. (1971) Competitive protein binding radioassay for 25-hydroxycholecalciferol. Journal of Clinical Endocrinology and Metabolism, 33, 992.

MERZ, W.A. \& SCHENK, R.K. (1970) Quantitative structural analysis of human cancellous bone. Acta anatomica (Basel), 75, 54.

Mosekilde, L., Melsen, F., Hessov, I., Christiensen, M.S., LUND, B.J., LUND, B.I. \& SORENSEN, O.H. (1980) Low serum levels of 1,25-dihydroxy vitamin $D$ and histomorphometric evidence of osteomalacia after jejunoilieal bypass for obesity. Gut, 21, 624.

Parfitt, A.M., Miller, M.J., Frame, B., Villanueva, A.R., RaO, D.S., OLIVER, I. \& THOMSON, D.O. (1978) Metabolic bone disease after intestinal bypass for treatment of obesity. Annals of Internal Medicine, 89, 193.

PAYNE, J.H. \& DEWIND, L. (1969) Surgical treatment of obesity. American Journal of Surgery, 118, 141.

PhILliPS, R.B. (1978) Small intestinal bypass for the treatment of morbid obesity. Surgery, Gynecology and Obstetrics, 146, 455.

Simonds, D.J., Hyland, G., LESKER, P.A., COHEN, M., STEIN, T. \& WISE, L. (1975) The effects of small bowel resection or bypass on the rat skeleton. Surgery, 78, 460.

THODE, J., MADSEN, S.N. \& HEY, H. (1978) Vitamin D and jejunoileal bypass. Lancet, ii, 264.

(Accepted 14 October 1982) 